\title{
Land Cover Differences in Soil Carbon and Nitrogen at Fort Benning, Georgia
}

January 2004

C.T. Garten, Jr., and T.L. Ashwood

Environmental Sciences Division

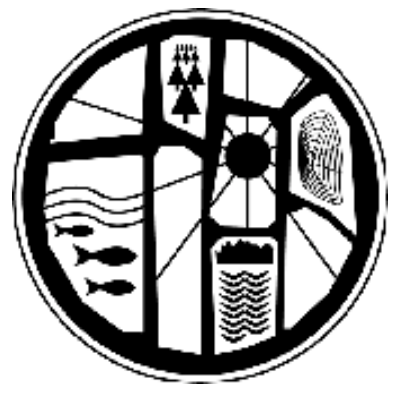




\section{DOCUMENT AVAILABILITY}

Reports produced after January 1, 1996, are generally available free via the U.S. Department of Energy (DOE) Information Bridge.

Web site http://www.osti.gov/bridge

Reports produced before January 1, 1996, may be purchased by members of the public from the following source.

National Technical Information Service

5285 Port Royal Road

Springfield, VA 22161

Telephone 703-605-6000 (1-800-553-6847)

TDD 703-487-4639

Fax 703-605-6900

E-mail info@ntis.fedworld.gov

Web site http://www.ntis.gov/support/ordernowabout.htm

Reports are available to DOE employees, DOE contractors, Energy Technology Data Exchange (ETDE) representatives, and International Nuclear Information System (INIS) representatives from the following source.

Office of Scientific and Technical Information

P.O. Box 62

Oak Ridge, TN 37831

Telephone 865-576-8401

Fax 865-576-5728

E-mail reports@adonis.osti.gov

Web site http://www.osti.gov/contact.html

This report was prepared as an account of work sponsored by an agency of the United States Government. Neither the United States Government nor any agency thereof, nor any of their employees, makes any warranty, express or implied, or assumes any legal liability or responsibility for the accuracy, completeness, or usefulness of any information, apparatus, product, or process disclosed, or represents that its use would not infringe privately owned rights. Reference herein to any specific commercial product, process, or service by trade name, trademark, manufacturer, or otherwise, does not necessarily constitute or imply its endorsement, recommendation, or favoring by the United States Government or any agency thereof. The views and opinions of authors expressed herein do not necessarily state or reflect those of the United States Government or any agency thereof. 
Environmental Sciences Division

\title{
LAND COVER DIFFERENCES IN SOIL CARBON AND NITROGEN AT FORT BENNING, GEORGIA
}

\author{
C.T. Garten, Jr., and T.L. Ashwood ${ }^{1}$ \\ Environmental Sciences Division \\ Oak Ridge National Laboratory
}

Date Published: January 2004

\author{
Prepared for \\ Strategic Environmental Research and Development Program (SERDP) \\ Ecosystem Management Program (SEMP) \\ Budget Activity Number 4015 ER 010 \\ Prepared by \\ OAK RIDGE NATIONAL LABORATORY \\ Oak Ridge, Tennessee 37831 \\ managed by \\ UT-BATTELLE, LLC \\ for the \\ U.S. DEPARTMENT OF ENERGY \\ under contract DE-AC05-00OR22725
}

\footnotetext{
${ }^{1}$ Retired
} 



\section{CONTENTS}

LIST OF TABLES...........................................................................

ACKNOWLEDGMENTS...................................................................... vii

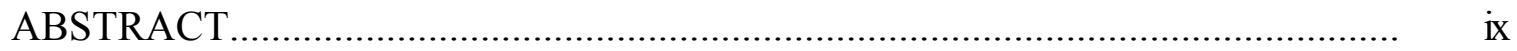

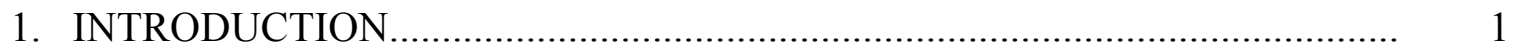

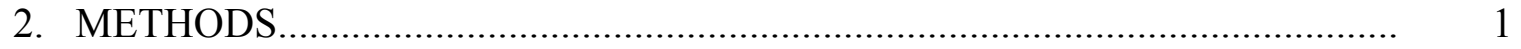

3. RESULTS AND DISCUSSION ................................................................ 3

3.1 SOIL DENSITY ...............................................................................

3.2 SOIL NITROGEN AVAILABILITY .................................................. 3

3.3 O-HORIZONS...................................................................................... 5

3.4 MINERAL SOIL CARBON AND NITROGEN...................................... 5

3.5 MAPS OF SOIL CARBON AND NITROGEN STOCKS....................... 7

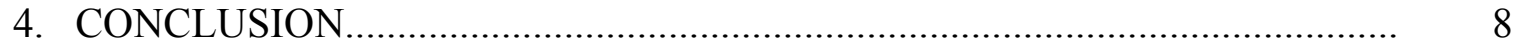

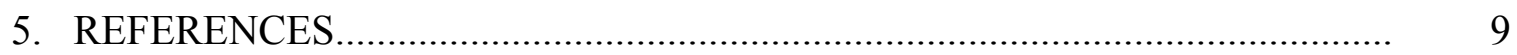





\section{LIST OF TABLES}

Table

Page

1 Mean $( \pm \mathrm{SE})$ soil density $\left(\mathrm{g} \mathrm{cm}^{-3}\right)$ under different land cover categories at Fort Benning, Georgia.....

2 Mean $( \pm \mathrm{SE})$ concentrations $\left(\mu \mathrm{g} \mathrm{N} \mathrm{g}^{-1}\right.$ soil) of extractable $(2 \mathrm{M} \mathrm{KCl})$ ammonium- and nitrate- $\mathrm{N}$ from surface $(0-20 \mathrm{~cm})$ mineral soil samples under different land cover categories at Fort Benning, Georgia......

3 Mean $( \pm \mathrm{SE})$ potential net soil nitrogen mineralization $\left(\mu \mathrm{g} \mathrm{N} \mathrm{g}{ }^{-1}\right.$ soil $)$ during a 12 week aerobic laboratory incubation and potential net nitrification ( $\mu \mathrm{g} \mathrm{N} \mathrm{g}^{-1}$ soil) during the first six weeks (phase 1) and the second six weeks (phase 2) of aerobic laboratory incubations of surface $(0-20 \mathrm{~cm})$ mineral soil.

4 Mean $( \pm \mathrm{SE})$ dry mass, carbon and nitrogen concentrations and stocks, and $\mathrm{C}: \mathrm{N}$ ratios in the O-horizons under different land cover categories at Fort Benning, Georgia.....

5 Mean $( \pm \mathrm{SE})$ soil carbon and nitrogen stocks as a function of soil depth under different land cover categories at Fort Benning, Georgia.....

6 Mean $( \pm \mathrm{SE})$ carbon stocks $\left(\mathrm{g} \mathrm{C} \mathrm{m}^{-2}\right)$ in particulate organic matter (POM-C), mineral-associated organic matter (MOM-C), a refractory part of POM (REF-C), and surface mineral soil $(0-20 \mathrm{~cm})$ under different land covers at Fort Benning, Georgia. 



\section{ACKNOWLEDGMENTS}

This research, project number CS-1114D-00, is a part of the Strategic Environmental Research and Development Program (SERDP) Ecosystem Management Project (SEMP) and was sponsored by the U.S. Department of Defense, in partnership with the U.S. Department of Energy and the U.S. Environmental Protection Agency. Oak Ridge National Laboratory (ORNL) is managed by UT-Battelle, LLC, for the U.S. Department of Energy under contract DE-AC0500OR22725. We wish to thank Bonnie Lu (ORNL) along with student interns Deanne Brice and Kevin Smith for their contributions in the laboratory and Robert Washington-Allen (ORNL) and Latha Baskaran (ORNL) for their help with the Fort Benning land cover map. Theresa Davo (Fort Benning) provided invaluable assistance with the identification of sampling sites. We thank Hal Balbach, U.S. Army Corps of Engineer's Construction Engineering Research Laboratory, for his helpful comments on the draft manuscript. We also wish to acknowledge the gracious assistance of personnel located at Fort Benning, especially Hugh Westbury, John Brent, and Pete Swiderek. 



\begin{abstract}
Land cover characterization might help land managers assess the impacts of management practices and land cover change on attributes linked to the maintenance and/or recovery of soil quality. However, connections between land cover and measures of soil quality are not well established. The objective of this limited investigation was to examine differences in soil carbon and nitrogen among various land cover types at Fort Benning, Georgia. Forty-one sampling sites were classified into five major land cover types: deciduous forest, mixed forest, evergreen forest or plantation, transitional herbaceous vegetation, and barren land. Key measures of soil quality (including mineral soil density, nitrogen availability, soil carbon and nitrogen stocks, as well as properties and chemistry of the O-horizon) were significantly different among the five land covers. In general, barren land had the poorest soil quality. Barren land, created through disturbance by tracked vehicles and/or erosion, had significantly greater soil density and a substantial loss of carbon and nitrogen relative to soils at less disturbed sites. We estimate that recovery of soil carbon under barren land at Fort Benning to current day levels under transitional vegetation or forests would require about 60 years following reestablishment of vegetation. Maps of soil carbon and nitrogen were produced for Fort Benning based on a 1999 land cover map and field measurements of soil carbon and nitrogen stocks under different land cover categories.
\end{abstract}

Key words: soil quality, soil nitrogen, soil carbon, particulate organic matter, ecosystem recovery, land management, soil management, military land 


\section{INTRODUCTION}

Military land managers are faced with the challenge of using a fixed amount of land for the purpose of training and troop readiness. Ideally, this mission must be accomplished in a manner that promotes the sustainability of ecosystems and the maintenance of soil quality; otherwise, the military mission may be compromised by a degraded landscape and conflicts with regulatory agencies. Organic matter (or soil carbon) and nitrogen availability are critical components of soil quality (Doran and Parkin, 1996). Numerous studies (e.g., Compton et al., 1998; Compton and Boone, 2000; Garten and Ashwood, 2002) indicate that there are land cover differences in processes related to soil nitrogen availability. However, associations between land cover type and other measures of soil quality have been less well studied.

Land cover can be readily classified on the basis of remote sensing data that are increasingly available at multiple spatial scales. Land cover is also amenable to management for enhancing or restoring soil quality on degraded land. Associations between land cover and soil quality could be valuable for local and regional assessments of how land cover change potentially reflects changes in soil quality. However, if land cover characterization is to be used effectively in soil management, then a better understanding of soil quality under different land covers is needed. The objectives of this limited investigation was to determine how measures of soil quality differ among five land cover types at Fort Benning, Georgia, and to develop maps of soil carbon and nitrogen stocks across the installation based on field measurements.

\section{METHODS}

Fort Benning is located near Columbus, Georgia. Current land cover is $49 \%$ mixed forest, $25 \%$ deciduous forest, $10 \%$ barren or developed land, $7 \%$ evergreen forest, $6 \%$ herbaceous grasslands, $2 \%$ shrub land, and 1\% water (Jones and Davo, 1997). Most soils at the site are highly weathered Ultisols derived from coastal plain or alluvial deposits. Sands and loamy sands are common on upland sites while sandy loams and sandy clay loams are found in valleys and riparian areas. Human activities that potentially produce soil disturbance include infantry, artillery, and wheeled and tracked vehicle training, as well as forest management practices. Further details on the biology, geology, physical setting, and history of Fort Benning are presented elsewhere (Jones and Davo, 1997).

Forty-one sampling sites were selected using on-the-ground surveillance and a Geographic Information System that included five major land cover types at Fort Benning: (1) deciduous forest, (2) mixed forest, (3) evergreen forest or plantation, (4) transitional land, and (5) barren land. Deciduous forests were comprised of various hardwoods (Quercus, Carya, Acer, Liquidambar, Liriodendron, Betula, Fagus) while evergreen forests included stands of longleaf (Pinus palustris), loblolly ( $P$. taeda), shortleaf ( $P$. echinata), slash (P. elliotti) and mixed pines. The mixed forest type included both pine/hardwood and hardwood/pine stands. Transitional lands were occupied by herbaceous annual and perennial vegetation and no overstory trees. 
Barren land included training sites and erosional areas more than 95\% devoid of surface vegetation.

Each site was treated as a single sampling unit and eight to nine sites were sampled within each land cover category in March, 2000. Three soil samples were collected at each site. The first sample (0-20 cm of mineral soil) was collected by hammering a PVC pipe $(5.1 \mathrm{~cm}$ inner diameter) into the soil. Two remaining mineral soil samples $(0-40 \mathrm{~cm})$ were collected in butyrate plastic tubes using a soil recovery probe $(2.54 \mathrm{~cm}$ inner diameter) with hammer attachment (AMS, American Falls, ID). Soil compression was minimal in the dominantly coarse textured soils at the study sites. When present, the O-horizon was sampled directly above each point sampled with the soil probe.

Mineral soil samples taken with the soil probe were cut into $10 \mathrm{~cm}$ depth increments and equivalent depth increments from each site were composited. Soil density $\left(\mathrm{g} \mathrm{cm}^{-3}\right)$ was estimated from the dry mass of soil in each depth increment and the calculated increment volume. Ohorizon samples were oven dried $\left(65^{\circ} \mathrm{C}\right)$ and mineral soil samples were air-dried to a constant mass. Mineral soil samples were crushed with a rubber mallet to pass a $2 \mathrm{~mm}$ sieve prior to elemental analysis. Carbon and nitrogen concentrations in dry, powdered samples were determined using a Perkin-Elmer 2400 Series II CHNS/O Analyzer (Perkin-Elmer Analytical Instruments, Norwalk, CT) and a LECO CN-2000 (LECO Corporation, St. Joseph, MI).

Soil samples collected with the soil probe were used to determine the depth profile and amounts of soil carbon and nitrogen under different land cover types. Carbon and nitrogen stocks $\left(\mathrm{g} \mathrm{m}^{-2}\right)$ in the O-horizon were calculated as the product of concentration $\left(\mathrm{g} \mathrm{C} \mathrm{g}^{-1}\right.$ or $\left.\mathrm{g} \mathrm{N} \mathrm{g}^{-1}\right)$ and dry mass per unit area $\left(\mathrm{g} \mathrm{m}^{-2}\right)$. Carbon and nitrogen stocks $\left(\mathrm{g} \mathrm{m}^{-2}\right)$ in each mineral soil increment were calculated as a product of concentration $\left(\mathrm{g} \mathrm{C} \mathrm{g}^{-1}\right.$ or $\left.\mathrm{g} \mathrm{N} \mathrm{g}^{-1}\right)$, soil density $\left(\mathrm{g} \mathrm{cm}^{-3}\right)$, and increment length $(\mathrm{cm})$.

Soil samples collected using PVC pipes were used for determination of potential net soil nitrogen mineralization and nitrification in 12-week aerobic laboratory incubations using methods described elsewhere (Garten and Ashwood, 2002). Portions of these samples were also physically separated into particulate organic matter (POM) and mineral-associated organic matter (MOM) (Cambardella and Elliott, 1992) using methods described in other papers (Garten and Ashwood, 2002; Garten et al., 2003). The total soil carbon stock (to a depth of $20 \mathrm{~cm}$ ) was subdivided among POM (corrected for refractory soil carbon), MOM, and refractory soil carbon. Refractory soil carbon in POM was evaluated using acid-base digestions (see Garten et al., 2003).

Differences among data grouped by land cover category were tested using analysis of variance (ANOVA). Differences between means were evaluated using Fisher's least significant difference (LSD). Unless stated otherwise, statistical significance was indicated by $P \leq 0.05$. The standard error $( \pm \mathrm{SE})$ was used to summarize the variability about each mean.

A 1999 land cover map was obtained for Fort Benning from the University of Georgia's Natural 
Resources Spatial Analysis Laboratory. The land cover categories, identified on the basis of remote sensing (LANDSAT), were water, bare ground, non-forest vegetation, pine forest, mixed forest, and deciduous forest. For the purpose of the spatial analysis, we assumed that non-forest vegetation corresponded to the land cover category designated "transitional vegetation". Measured mean values for soil carbon and nitrogen stocks in the O-horizon and the mineral soil $(0-20 \mathrm{~cm})$ were assigned to the different land cover categories to produce maps illustrating an hypothesized spatial distribution of soil carbon and nitrogen across Fort Benning.

\section{RESULTS AND DISCUSSION}

\subsection{SOIL DENSITY}

At all increment depths, soil density was significantly greater under barren land than under deciduous or mixed forests on Fort Benning (Table 1). Studies of military training on dry sandy soils indicate that surface soil compaction caused by heavy, tracked vehicles can persist for decades (Iverson et al., 1981). Heavy machinery is also used to harvest and establish pine plantations. Land use that promotes soil compaction is concentrated on those land cover categories that have the highest soil densities. Barren soils have been created primarily through disturbance associated with heavy, tracked vehicles. Transitional areas include grassy fields that are maintained for vehicle maneuvers, parachute jump zones, and areas in early stages of secondary succession following forest clearing. Deciduous and mixed forests are subject to lowintensity impacts from infantry (foot or dismounted) training, and their large spatial coverage (74\% of the total land area) probably "dilutes" human activities that could promote soil compaction throughout Fort Benning.

\subsection{SOIL NITROGEN AVAILABILITY}

Extractable soil ammonium, at the beginning of aerobic laboratory incubations, was significantly greater under mixed and deciduous forest stands than under barren land $\left(\mathrm{F}_{4,36}=2.8 ; P \leq 0.05\right)$. In contrast, extractable soil nitrate was significantly greater under barren land than under forests $\left(\mathrm{F}_{4,36}=4.7 ; P \leq 0.01\right)$. Concentrations of extractable soil ammonium and nitrate under transitional vegetation were intermediate between those for barren soils and soils under mixed and deciduous forest cover (Table 2).

Potential net nitrogen mineralization $\left(\mathrm{F}_{4,36}=4.8 ; P \leq 0.01\right)$ and nitrification $\left(\mathrm{F}_{4,36}=3.5 ; P \leq 0.05\right)$ in surface mineral soils differed among the various land cover types (Table 3). Variation in soil nitrogen transformations at Fort Benning was complex, but the results indicated greater soil nitrogen availability under deciduous forests, mixed forests, and transitional vegetation than under evergreen forests and barren land. Most of the potential net nitrogen mineralization in laboratory incubations terminated in nitrate production, however there was a pronounced lag in the onset of net nitrification under forest soils that was not observed in soils under barren land and transitional vegetation. High concentrations of extractable soil nitrate in barren soils were 
consistent with the absence of a time lag in the onset of net nitrification, and may indicate a pool of unused nitrogen that originates from atmospheric deposition.

Table 1. Mean $( \pm \mathrm{SE})$ soil density $\left(\mathrm{g} \mathrm{cm}^{-3}\right)$ under different land cover categories at Fort Benning, Georgia*

\begin{tabular}{|c|c|c|c|c|c|c|}
\hline \multirow{2}{*}{$\begin{array}{c}\text { Soil depth } \\
(\mathrm{cm})\end{array}$} & Barren & $\begin{array}{c}\text { Transitional } \\
\text { land }\end{array}$ & $\begin{array}{c}\text { Evergreen } \\
\text { forest }\end{array}$ & $\begin{array}{c}\text { Mixed } \\
\text { forest }\end{array}$ & $\begin{array}{c}\text { Deciduous } \\
\text { forest }\end{array}$ & \multirow{2}{*}{ F-value $^{\dagger}$} \\
\cline { 2 - 6 } & $1.64^{\mathrm{a}}$ & $\begin{array}{c}1.37^{\mathrm{b}} \\
\pm 0.06\end{array}$ & $\begin{array}{c}1.32^{\mathrm{b}} \\
\pm 0.06\end{array}$ & $\begin{array}{c}1.16^{\mathrm{c}} \\
\pm 0.04\end{array}$ & $\begin{array}{c}1.10^{\mathrm{c}} \\
\pm 0.04\end{array}$ & $\begin{array}{c}18.5 \\
(P<0.001)\end{array}$ \\
\hline $10-02$ & $1.71^{\mathrm{a}}$ & $1.60^{\mathrm{ab}}$ & $1.43^{\mathrm{bc}}$ & $1.34^{\mathrm{c}}$ & $1.34^{\mathrm{c}}$ & 6.1 \\
\pm 0.05 & \pm 0.10 & \pm 0.06 & \pm 0.05 & $(P<0.001)$ \\
\hline $20-30$ & $1.72^{\mathrm{a}}$ & $1.61^{\mathrm{ab}}$ & $1.52^{\mathrm{bc}}$ & $1.36^{\mathrm{bc}}$ & $1.41^{\mathrm{c}}$ & 4.4 \\
& \pm 0.03 & \pm 0.08 & \pm 0.09 & \pm 0.08 & \pm 0.04 & $(P<0.01)$ \\
\hline $30-40$ & $1.68^{\mathrm{a}}$ & $1.57^{\mathrm{ab}}$ & $1.60^{\mathrm{ab}}$ & $1.39^{\mathrm{b}}$ & $1.47^{\mathrm{b}}$ & 2.7 \\
& \pm 0.03 & \pm 0.09 & \pm 0.06 & \pm 0.08 & \pm 0.06 & $(P<0.05)$ \\
\hline
\end{tabular}

* Means in the same row with different alphabetic superscripts are significantly different $\dagger$ degrees of freedom $(\mathrm{df})=4,36$ for each F-value, except $30-40 \mathrm{~cm}$ where $\mathrm{df}=4,33$

Table 2. Mean $( \pm \mathrm{SE})$ concentrations $\left(\mu \mathrm{g} \mathrm{N} \mathrm{g}^{-1}\right.$ soil) of extractable (2 M KCl) ammoniumand nitrate- $\mathrm{N}$ from surface $(0-20 \mathrm{~cm})$ mineral soil samples under different land cover categories at Fort Benning, Georgia*

\begin{tabular}{|c|c|c|c|c|c|c|}
\hline \multirow[b]{2}{*}{$\begin{array}{l}\text { Form of } \\
\text { nitrogen }\end{array}$} & \multicolumn{5}{|c|}{ Land cover category } & \multirow[b]{2}{*}{ F-value } \\
\hline & Barren & $\begin{array}{c}\text { Transitional } \\
\text { land }\end{array}$ & $\begin{array}{c}\text { Evergreen } \\
\text { forest }\end{array}$ & $\begin{array}{l}\text { Mixed } \\
\text { forest }\end{array}$ & $\begin{array}{l}\text { Deciduous } \\
\text { forest }\end{array}$ & \\
\hline $\mathrm{NO}_{3}-\mathrm{N}$ & $\begin{array}{l}0.68^{\mathrm{a}} \\
\pm 0.23\end{array}$ & $\begin{array}{l}0.38^{\mathrm{ab}} \\
\pm 0.07\end{array}$ & $\begin{array}{l}0.13^{b} \\
\pm 0.03\end{array}$ & $\begin{array}{l}0.18^{b} \\
\pm 0.04\end{array}$ & $\begin{array}{l}0.13^{\mathrm{b}} \\
\pm 0.03\end{array}$ & $\begin{array}{c}4.7 \\
(P<0.01)\end{array}$ \\
\hline $\mathrm{NH}_{4}-\mathrm{N}$ & $\begin{array}{l}0.37^{\mathrm{a}} \\
\pm 0.16\end{array}$ & $\begin{array}{l}1.48^{\mathrm{ab}} \\
\pm 0.36\end{array}$ & $\begin{array}{l}1.32^{\mathrm{ab}} \\
\pm 0.22\end{array}$ & $\begin{array}{l}2.41^{b} \\
\pm 0.74\end{array}$ & $\begin{array}{l}2.12^{b} \\
\pm 0.60\end{array}$ & $\begin{array}{c}2.8 \\
(P<0.05)\end{array}$ \\
\hline Inorganic $\mathrm{N}$ & $\begin{array}{r}1.05^{\mathrm{a}} \\
\pm 0.32\end{array}$ & $\begin{array}{r}1.85^{\mathrm{a}} \\
\pm 0.35\end{array}$ & $\begin{array}{r}1.45^{\mathrm{a}} \\
\pm 0.23\end{array}$ & $\begin{array}{r}2.58^{a} \\
\pm 0.77\end{array}$ & $\begin{array}{r}2.26^{\mathrm{a}} \\
\pm 0.61\end{array}$ & 1.6 \\
\hline
\end{tabular}

* Means in the same row with different alphabetic superscripts are significantly different 


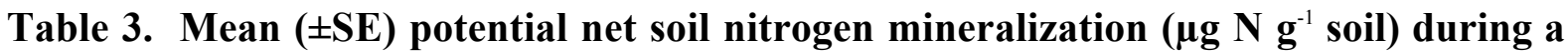
12 week aerobic laboratory incubation and potential net nitrification $\left(\mu \mathrm{g} \mathrm{N} \mathrm{g}^{-1}\right.$ soil) during the first six weeks (phase 1) and the second six weeks (phase 2) of aerobic laboratory incubations of surface $(0-20 \mathrm{~cm})$ mineral soil*

\begin{tabular}{|c|c|c|c|c|c|c|}
\hline \multirow[b]{2}{*}{$\begin{array}{l}\mathrm{N} \text { production } \\
\left(\mu \mathrm{g} \mathrm{N} \mathrm{g}{ }^{-1} \text { soil }\right)\end{array}$} & \multicolumn{5}{|c|}{ Land cover category } & \multirow[b]{2}{*}{ F-value } \\
\hline & Barren & $\begin{array}{l}\text { Transitional } \\
\text { land }\end{array}$ & $\begin{array}{l}\text { Evergreen } \\
\text { forest }\end{array}$ & $\begin{array}{l}\text { Mixed } \\
\text { forest }\end{array}$ & $\begin{array}{c}\text { Deciduous } \\
\text { forest }\end{array}$ & \\
\hline $\begin{array}{c}\text { Net soil } \mathrm{N} \\
\text { mineralization }\end{array}$ & $\begin{array}{l}1.79^{\mathrm{a}} \\
\pm 1.01\end{array}$ & $\begin{array}{l}9.93 \mathrm{bc} \\
\pm 1.97\end{array}$ & $\begin{array}{l}5.41^{\mathrm{ab}} \\
\pm 2.25\end{array}$ & $\begin{array}{l}11.08^{\mathrm{bc}} \\
\pm 2.77\end{array}$ & $\begin{array}{l}12.83^{\mathrm{c}} \\
\pm 1.80\end{array}$ & $\begin{array}{c}4.8 \\
(P<0.01)\end{array}$ \\
\hline $\begin{array}{l}\text { Net nitrification } \\
\quad \text { (phase 1) }\end{array}$ & $\begin{array}{l}1.01^{\mathrm{a}} \\
\pm 0.43\end{array}$ & $\begin{array}{l}4.51^{\mathrm{b}} \\
\pm 1.45\end{array}$ & $\begin{array}{l}1.05^{\mathrm{a}} \\
\pm 0.85\end{array}$ & $\begin{array}{r}0.84^{\mathrm{a}} \\
\pm 0.53\end{array}$ & $\begin{array}{l}1.43^{\mathrm{a}} \\
\pm 0.35\end{array}$ & $\begin{array}{c}3.5 \\
(P<0.05)\end{array}$ \\
\hline $\begin{array}{l}\text { Net nitrification } \\
\quad \text { (phase 2) }\end{array}$ & $\begin{array}{l}0.81^{\mathrm{a}} \\
\pm 0.70\end{array}$ & $\begin{array}{l}5.56^{\mathrm{ab}} \\
\pm 1.10\end{array}$ & $\begin{array}{l}3.42^{\mathrm{a}} \\
\pm 1.25\end{array}$ & $\begin{array}{l}6.53^{\mathrm{b}} \\
\pm 2.42\end{array}$ & $\begin{array}{l}9.60^{\mathrm{b}} \\
\pm 2.17\end{array}$ & $\begin{array}{c}4.0 \\
(P<0.01)\end{array}$ \\
\hline
\end{tabular}

* Means in the same row with different alphabetic superscripts are significantly different

\subsection{O-HORIZONS}

At Fort Benning, both the dry mass and chemistry of the O-horizon differed significantly among land cover types (Table 4). For nonbarren land cover categories, O-horizon dry mass and nitrogen stocks were greatest under deciduous forests and least under transitional vegetation. The O-horizon C:N ratio was significantly elevated under evergreen and mixed forest stands.

Net soil nitrogen mineralization is affected by litter quality (Scott and Binkley, 1997). Low Ohorizon $\mathrm{C}: \mathrm{N}$ ratios under deciduous forests and transitional land covers may promote greater net soil nitrogen mineralization (Table 3). High O-horizon C:N ratios under evergreen forests may reduce net soil nitrogen mineralization by promoting microbial immobilization of nitrogen.

\subsection{MINERAL SOIL CARBON AND NITROGEN}

Data from different forest types were combined for a depth profile analysis of mineral soil carbon and nitrogen because mineral soil carbon and nitrogen stocks at Fort Benning were not significantly different among the three forest categories. The depth profiles indicated that creation of barren land by heavy, tracked vehicles and/or erosion, results in a substantial loss of soil carbon and nitrogen (Table 5). For each depth increment examined, soil carbon and nitrogen stocks under barren land were significantly less than those under other land covers. On average, in the surface $(0-20 \mathrm{~cm})$ mineral soil, there was more than an $80 \%$ loss of $\mathrm{C}$ and more than a $60 \%$ loss of $\mathrm{N}$ under barren land. 
Table 4. Mean ( \pm SE) dry mass, carbon and nitrogen concentrations and stocks, and $\mathrm{C}: \mathrm{N}$ ratios in the O-horizons under different land cover categories at Fort Benning, Georgia*

\begin{tabular}{|c|c|c|c|c|c|c|}
\hline \multirow{2}{*}{$\begin{array}{c}\text { O-horizon } \\
\text { property }\end{array}$} & \multicolumn{5}{|c|}{ Land cover category } & \multirow{2}{*}{} \\
\cline { 2 - 6 } & Barren & $\begin{array}{c}\text { Transitional } \\
\text { land }\end{array}$ & $\begin{array}{c}\text { Evergreen } \\
\text { forest }\end{array}$ & $\begin{array}{c}\text { Mixed } \\
\text { forest }\end{array}$ & $\begin{array}{c}\text { Deciduous } \\
\text { forest }\end{array}$ & F-value $^{\dagger}$ \\
\hline Dry mass & $0.0^{\mathrm{a}}$ & $894^{\mathrm{b}}$ & $1053^{\mathrm{b}}$ & $1152^{\mathrm{bc}}$ & $1821^{\mathrm{c}}$ & 7.4 \\
$\left(\mathrm{~g} \mathrm{~m}^{-2}\right)$ & & \pm 474 & \pm 123 & \pm 128 & \pm 193 & $(P<0.001)$ \\
\hline Carbon & -- & $18.3^{\mathrm{a}}$ & $40.1^{\mathrm{b}}$ & $37.5^{\mathrm{c}}$ & $30.2^{\mathrm{c}}$ & 33.9 \\
$(\%)$ & & \pm 2.2 & \pm 1.5 & \pm 1.6 & \pm 1.2 & $(P<0.001)$ \\
\hline Nitrogen & -- & $0.54^{\mathrm{a}}$ & $0.54^{\mathrm{a}}$ & $0.72^{\mathrm{b}}$ & $0.79^{\mathrm{b}}$ & 10.3 \\
$(\%)$ & & \pm 0.05 & \pm 0.03 & \pm 0.02 & \pm 0.06 & $(P<0.001)$ \\
\hline Carbon stock & -- & $136^{\mathrm{a}}$ & $413^{\mathrm{b}}$ & $422^{\mathrm{bc}}$ & $536^{\mathrm{c}}$ & 15.4 \\
$\left(\mathrm{~g} \mathrm{C} \mathrm{m}^{-2}\right)$ & & \pm 59 & \pm 39 & \pm 37 & \pm 31 & $(P<0.001)$ \\
\hline Nitrogen stock & -- & $5.3^{\mathrm{a}}$ & $5.7^{\mathrm{a}}$ & $8.3^{\mathrm{a}}$ & $14.9^{\mathrm{b}}$ & 5.1 \\
$\left(\mathrm{~g} \mathrm{~N} \mathrm{~m}^{-2}\right)$ & & \pm 3.0 & \pm 0.8 & \pm 1.0 & \pm 2.4 & $(P<0.01)$ \\
\hline C:N ratio & -- & $34.5^{\mathrm{a}}$ & $76.5^{\mathrm{b}}$ & $52.1^{\mathrm{c}}$ & $39.9^{\mathrm{a}}$ & 25.1 \\
& & \pm 4.2 & \pm 4.3 & \pm 2.3 & \pm 3.9 & $(P<0.001)$ \\
\hline
\end{tabular}

* Means in the same row with different alphabetic superscripts are significantly different $\dagger \mathrm{df}=3,27$ for each F-value, except for O-horizon dry mass where $\mathrm{df}=4,36$

Table 5. Mean $( \pm \mathrm{SE})$ soil carbon and nitrogen stocks as a function of soil depth under different land cover categories at Fort Benning, Georgia

\begin{tabular}{|c|c|c|c|c|c|c|}
\hline \multirow{2}{*}{$\begin{array}{c}\text { Soil depth } \\
(\mathrm{cm})\end{array}$} & \multicolumn{3}{|c|}{ Soil carbon stock $\left(\mathrm{g} \mathrm{C} \mathrm{m}^{-2}\right)$} & \multicolumn{3}{c|}{ Soil nitrogen stock $\left(\mathrm{g} \mathrm{N} \mathrm{m}^{-2}\right)$} \\
\cline { 2 - 7 } & Barren & $\begin{array}{c}\text { Transitional } \\
\text { land }\end{array}$ & Forest & Barren & $\begin{array}{c}\text { Transitional } \\
\text { land }\end{array}$ & Forest \\
\hline $0-10$ & $292 \pm 106$ & $1616 \pm 188$ & $1658 \pm 126$ & $21.1 \pm 4.6$ & $86.8 \pm 16.1$ & $81.7 \pm 8.2$ \\
\hline $10-20$ & $238 \pm 92$ & $963 \pm 103$ & $767 \pm 61$ & $19.3 \pm 5.2$ & $49.3 \pm 7.4$ & $40.4 \pm 4.2$ \\
\hline $20-30$ & $185 \pm 68$ & $528 \pm 61$ & $560 \pm 61$ & $14.8 \pm 4.3$ & $38.2 \pm 7.3$ & $35.3 \pm 4.0$ \\
\hline $30-40$ & $148 \pm 60$ & $364 \pm 30$ & $425 \pm 49$ & $14.4 \pm 3.9$ & $32.1 \pm 5.1$ & $31.2 \pm 2.9$ \\
\hline
\end{tabular}

Partitioning of soil carbon stocks is important because various soil carbon pools may exhibit different sensitivities to a change in land cover. Soil carbon partitioning also reveals the potential for soil carbon and nitrogen change as a result of disturbance or land cover change. Carbon stocks in POM $\left(\mathrm{F}_{2,37}=9.9 ; P \leq 0.001\right)$, MOM $\left(\mathrm{F}_{2,38}=14.2 ; P \leq 0.001\right)$, and refractory $\left(\mathrm{F}_{2,37}=4.8 ; P\right.$ $\leq 0.05$ ) soil fractions differed significantly among various land cover types at Fort Benning (Table $6)$. 
Table 6. Mean $( \pm \mathrm{SE})$ carbon stocks $\left(\mathrm{g} \mathrm{C} \mathrm{m}^{-2}\right)$ in particulate organic matter (POM-C), mineral-associated organic matter (MOM-C), a refractory part of POM (REF-C), and surface mineral soil $(0-20 \mathrm{~cm})$ under different land covers at Fort Benning, Georgia*

\begin{tabular}{|c|c|c|c|c|}
\hline \multirow{2}{*}{$\begin{array}{c}\text { Soil carbon } \\
\text { fraction }\end{array}$} & \multicolumn{3}{|c|}{ Land cover category } & \multirow{2}{*}{ F-value } \\
\cline { 2 - 4 } & Barren & Transitional land & Forest & \\
\hline POM-C & $73^{\mathrm{a}}$ & $462^{\mathrm{b}}$ & $474^{\mathrm{b}}$ & 9.9 \\
\pm 26 & \pm 75 & $1716^{\mathrm{b}}$ & 14.2 \\
& $421^{\mathrm{a}}$ & $1790^{\mathrm{b}}$ & \pm 132 & $(P<0.001)$ \\
\hline MOM-C & \pm 157 & \pm 236 & $247^{\mathrm{b}}$ & 4.8 \\
& $34^{\mathrm{a}}$ & $297^{\mathrm{b}}$ & \pm 45 & $(P<0.05)$ \\
\hline REF-C & \pm 19 & \pm 54 & $2433^{\mathrm{b}}$ & 19.9 \\
& $529^{\mathrm{a}}$ & $2548^{\mathrm{b}}$ & \pm 169 & $(P<0.001)$ \\
\hline Total & \pm 197 & \pm 257 & & \\
& & &
\end{tabular}

* Means in the same row with different alphabetic superscripts are significantly different

Based on other studies (e.g., see Garten and Ashwood, 2002), carbon in mineral-associated organic matter is expected to have a longer turnover time than carbon in particulate organic matter. Based on acid-base digestions, one-third of the carbon in particulate organic matter was refractory. We are unable to provide a precise chemical analysis of this refractory carbon, but it has chemical properties similar to charcoal (Garten et al., 2003) and probably originates from controlled ground fires that are regularly used for forest management at Fort Benning.

\subsection{MAPS OF SOIL CARBON AND NITROGEN STOCKS}

Figure 1 illustrates the hypothesized spatial distribution of soil carbon and nitrogen stocks at Fort Benning based on field measurements under different land cover categories and a 1999 land cover map. The highest O-horizon and surface mineral soil carbon stocks tend to occur in areas adjacent to stream drainages (e.g., Wolf Creek, Randal Creek, and Upatoi Creek in the northern part and Oswichee Creek in the southern part of the Fort Benning). Training areas in the northeastern corner and developed areas on the eastern edge of the installation are characterized by the lowest O-horizon carbon and nitrogen stocks. In the present maps (Figure 1), the hypothesized distribution of soil nitrogen is complex with no apparent higher stocks along streams and creeks, but high nitrogen stocks occur under herbaceous cover on transitional land. Nitrogen fixing plants, which are more prevalent in successional herbaceous communities than under forest cover, may contribute to greater soil nitrogen storage on transitional lands. 


\section{CONCLUSION}

Although limited in scope, this small study indicates that military land managers at Fort Benning might infer differences in some measures of soil quality, like soil nitrogen availability and Ohorizon properties, based on characterization of land cover. However, other measures (like soil carbon stocks) were similar under non-barren land cover categories indicating that ecosystem type was less useful for inferring some aspects of soil quality than the mere presence of perennial vegetation. Land cover change at barren sites on Fort Benning will probably require human intervention to accelerate recovery of soil quality for ecosystem rehabilitation. Following reestablishment of vegetation on barren sites and at an average rate of soil carbon accumulation beneath perennial vegetation, approximately $33 \mathrm{~g} \mathrm{C} \mathrm{m}^{-2} \mathrm{yr}^{-1}$ (Post and Kwon, 2000), it would take about 60 years for soil carbon stocks at barren sites to reach current day levels under transitional vegetation or forest cover (Table 5). This predicted rate of recovery is consistent with an apparent slow accumulation of soil carbon stocks in particulate organic matter along a 100 year old pine chronosequence at Fort Benning, Georgia (Garten et al., 2003).
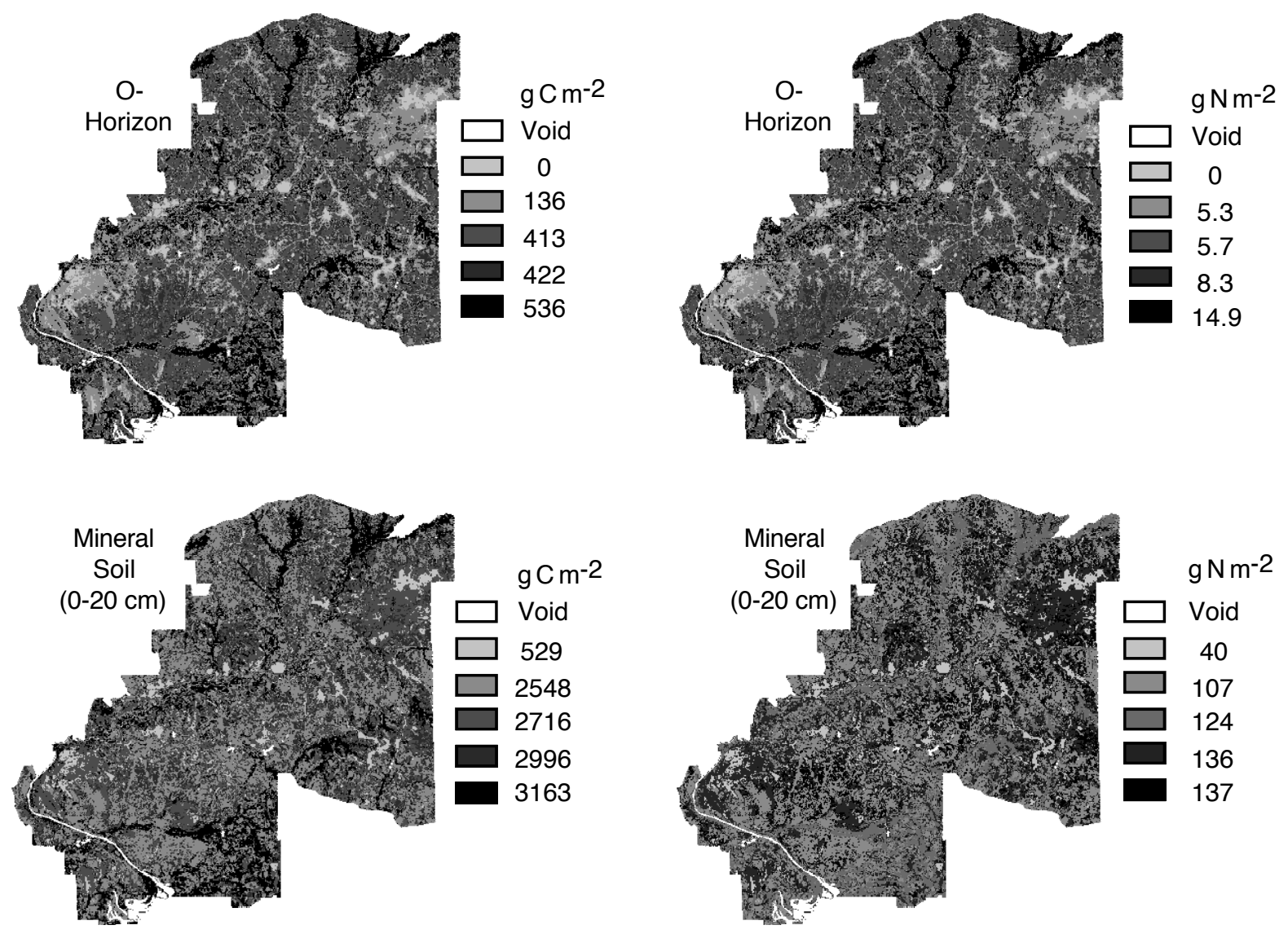

Fig. 1 Hypothesized spatial distribution of soil carbon and nitrogen stocks at Fort Benning based on the assignment of field measurements to an installation land cover map from 1999 


\section{REFERENCES}

Cambardella, C.A., Elliott, E.T., 1992. Particulate soil organic-matter changes across a grassland cultivation sequence. Soil Science Society of America Journal 56, 777-783.

Compton, J.E., Boone, R.D., 2000. Long-term impacts of agriculture on soil carbon and nitrogen in New England forests. Ecology 81, 2314-2330.

Compton, J.E., Boone, R.D., Motzkin, G., Foster, D.R., 1998. Soil carbon and nitrogen in a pine-oak sand plain in central Massachusetts: role of vegetation and land-use history. Oecologia 116, 536-542.

Doran, J.W., Parkin, T.B., 1996. Quantitative indicators of soil quality: a minimum data set. In: Doran, J.W., Jones, A.J. (Eds.), Methods for Assessing Soil Quality. Soil Science Society of America, Inc., Madison, pp. 25-37.

Garten, C.T., Jr., Ashwood, T.L., Dale, V.H., 2003. Effect of military training on indicators of soil quality at Fort Benning, Georgia. Ecological Indicators 3, 171-179.

Garten, C.T., Jr., Ashwood, T.L., 2002. Landscape level differences in soil carbon and nitrogen: implications for soil carbon sequestration. Global Biogeochemical Cycles 16 (4), article no. 1114.

Iverson, R.M., Hinckley, B.S., Webb, R.M., Hallet, B., 1981. Physical effects of vehicular disturbance on arid landscapes. Science 212, 915-917.

Jones, D.S., Davo, T., 1997. Land Condition-Trend Analysis Program Summary, Fort Benning, Georgia: 1991-1995. Center for Ecological Management of Military Lands, Colorado State University, Fort Collins, CO.

Post, W.M., Kwon, K.C., 2000. Soil carbon sequestration and land-use change: processes and potential. Global Change Biology 6, 317-327.

Scott, N.A., Binkley, D., 1997. Foliage litter quality and annual net N mineralization: comparison across North American forest sites. Oecologia 111, 151-159. 
ORNL/TM-2004/14

\section{INTERNAL DISTRIBUTION}

1-6. C.T. Garten, Jr., Bldg. 1505 (6038)

7. V.H. Dale, Bldg. 1505 (6036)

8. R.L. Graham, Bldg. 1505 (6036)

9. G.K. Jacobs, Bldg. 1505 (6035)

10. P.J. Mulholland, Bldg. 1505 (6036)

11. R. Washington-Allen, Bldg. 1505 (6407)
12-14. ESD Library

15. ORNL Central Research Library

16. ORNL Laboratory Records CRC

17. ORNL Laboratory Records BOSTI

\section{EXTERNAL DISTRIBUTION}

18. T.L. Ashwood, 418 Keota Lane, Loudon, TN 37774

19. H.E. Balbach, U.S. Army Engineer Research and Development Center (ERDC), P.O. Box 9005, Champaign, IL 61826-9005

20. W.D. Goran, U.S. Army Engineer Research and Development Center (ERDC), P.O. Box 9005, Champaign, IL 61826-9005

\section{ELECTRONIC NOTIFICATION}

21. Teresa Aden (Teresa.S.Aden@erdc.usace.army.mil)

22. Neil Burns (Burns.Neil@epamail.epa.gov)

23. John Brent (John.Brent@benning.army.mil)

24. Beverly Collins (collins@srel.edu)

25. Roger Dahlman (Roger.Dahlman@science.doe.gov)

26. John Dilustro (dilustro@srel.edu)

27. John Hall (john_hall@TNC.ORG)

28. Robert Holst (robert.holst@osd.mil)

29. Jennifer Jacobs (jjaco@ce.ufl.edu)

30. Louis Kaplan (lakaplan@stroudcenter.org)

31. Katherine Kirkman (kkirkman@jonesctr.org)

32. Rose Kress (kressr@wes.army.mil)

33. Tony Krzysik (krzysika@cableone.net)

34. Joe Prenger (jprenger@ufl.edu)

35. David Price (priced@wes.army.mil)

36. K. Ramesh Reddy (krr@mail.ifas.ufl.edu)

37. Pete Swiderek (swiderekp@benning.army.mil)

38. Hugh Westbury (Hugh.Westbury@Benning.Army.Mil) 